\title{
State, Education, and the Market
}

\author{
NAHEED ZIA KHAN \\ INTRODUCTION
}

The tail of the tail-end of the 2nd millennium has taught the humankind two valuable lessons: democracy and the market, although imperfect, have succeeded where other systems have failed. What is clear is that the most successful systems are aligned to humankind's predispositions rather than being inimical to them. Insofar as it aligns itself with the predisposition to greed, consistently regulated capitalism terms out to be the most efficient economic system hitherto observed in human society. Likewise, democracy works by aligning many people's desire for power with a governance system which on balance is helpful to the general population, unlike various forms of totalitarianism. But recent movements for both capitalism and democracy in many developing countries largely do not subscribe to humankind's predispositions, rather they appear to be a part of the headlong global trend towards these paradigms. The reason being that the most important ingredient, common to both recipes, is lacking in many developing countries: that is the popular pressure and mobilisation which is sufficiently informed of its duties and rights. This ingredient is most important as it forces out the authoritarian rule whether, totalitarian or 'democratic', and makes democratic governance drive the market to the maximum benefit of society. The central thesis of this work is that this most important ingredient is the result of an effective and efficient system of public institutions for free and compulsory universal primary schooling which, if the resource constraint could be overcome, ought to be supplemented by free and compulsory secondary schooling. The argument is structured in five parts. The primary motivation for writing Part I is to show that the normative stance of the language of the Classical economists has been complacently overlooked by their Rawalpindi.

Naheed Zia Khan is Assistant Professor of Economics at Fatima Jinnah Women's University, 
modern successors in orientation and emphasis. Part II attempts to portray a diachronic view of the central thesis, considering the experiences of selected developed and developing countries. The major motivation of the author appears in the subsequent parts: Part III compares Pakistan's score in mass education with other developing countries and regions, while in Part IV an effort has been made to pin down the factors responsible for the dismal scenario that emerges from Pakistan's comparative status. Finally, Part V offers the recommendations of this study.

\section{KINDLING THE 'KANDLES’: CASE FOR STATE RESPONSIBILITY}

Governance, institutional set up and economic development are interdependent factors. In any society, historic, medieval or modern, only the mutual consistency of these factors has ensured and endured a 'blue sky'. In the postindustrial era, however, their mutual consistency itself has been determined by the dynamic quality and proportionate quantity of the versatile skills acquired through formal education. The latter is universally regarded as fundamental to building a sense of common citizenship, a vehicle for social mobility, and a means of creating an effective workforce. An educated workforce has been a boon to productivity in both developed and developing countries. It has reduced inequality and increased occupational mobility.

The importance of education in development has been well recognised in the literature ever since the Nobel Laureates Theodore Schultz initiated 'human investment revolution in economic thought'. Nonetheless, the Chicago School's approach was later jolted by critics who argued that the productivity role of education was negligible [Arrow (1973); Spence (1973)]. But the setback proved only temporary. As a slow and steady re-emergence of faith in human capital marked the 1980s, developing countries and international agencies began paying serious attention to human investment. The contribution of education to economic growth is found to be positive and significant, not only in monetary terms, but, even more importantly, in physical terms such as farm efficiency and labour productivity. Education's contribution has also been found to be significant in the reduction of poverty, improvement in income distribution and in various dimensions of social, demographic and political development [Talik (1989, 1994)]. The relative significance of human capital has been found higher in developing countries, and in poor people, than in developed countries and rich people [Psacharopoulos (1984, 1994)].

The compartmentalised, societal acquisition of versatile skills, nicknamed as human capital formation, is a necessary but not sufficient condition for determining the course and pace of multidirectional-envelope economic development, unless the masses are compulsorily educated to appreciate their civic duties and rights. State, 
market and the 'in between' have universally determined the direction of the quest for finding solutions to all economic and social puzzles. History is the witness that only nations who could determine and practise an optimum 'in between' to run their institutions flourished with long lasting 'spread effects'. This is no where as true as it is in the realm of education.

In all developed and in an increasing number of developing countries, education is not regarded merely as a right, but as an obligation. Adoption of a compulsory school education policy was often established in societies before they began rapid economic growth. Adam Smith, the prophet of the market 'theology', was the first to present systematically the case for state intervention in education. In the Wealth of Nations, he wrote: "The man whose life is spent in performing a few simple operations, of which the effects too are, perhaps, always the same, or very nearly the same, has no occasion to exert his understanding, or to exercise his invention in finding out expedients for removing difficulties which never occur. He naturally loses, therefore the habit of such exertion, and generally becomes as stupid and ignorant as it is possible for a human creature to become. The torpor of his mind renders him, not only incapable of relishing or bearing a part in any rational conversation, but of conceiving any generous, noble, or tender sentiment, and consequently of forming any just judgement concerning many even of the ordinary duties of private life. It corrupts even the activity of his body, and renders him incapable of exerting his strength with vigour and perseverance, in any other employment than that to which he has been bred. His dexterity at his own particular trade seems, in this manner, to be acquired at the expense of his intellectual, social and martial values. But in every improved and civilised society this is the state into which the labouring poor, that is, the great body of the people, must necessarily fall, unless government takes some pains to prevent it [Smith (1937), p. 735]".

Smith questions: "Ought the public to give no attention, it may be asked, to the education of the people? Or if it ought to give any, what are the different parts of education which it ought to attend to in the different orders of the people? And what manner ought it to attend to them [ibid.]"?

He himself answers: "But though the common people cannot, in any civilised society, be so well instructed as people of some rank or fortune, the most essential part of education, however, to read, write, and account, can be acquired at so early a period of life, that the greater part even of those who are to be bred to the lowest occupation, have time to acquire them before they can be employed in those occupations. For a very small expense the public can facilitate, can encourage, and can even impose [emphasis added] upon almost the whole body of the people, the necessity of acquiring those most essential parts of education [ibid., p. 737]".

Does the state itself benefit from mass education? Adam Smith was not sceptical in the least. On the contrary, he was a zealous believer. He reasoned: "Of 
the great and extensive interests of his country he [the ignorant] is altogether incapable of judging; and unless very particular pains have been taken to render him otherwise, he is equally incapable of defending his country in war. The uniformity of his stationary life naturally corrupts the courage of his mind, and makes him regard with abhorrence the irregular, uncertain and adventurous life of a soldier [ibid. p. 735]".

He fervently held that "The state....derives no inconsiderable advantage from their instruction. The more they are instructed, the less liable they are to the delusions of enthusiasm and superstition, which, among ignorant nations, frequently occasions the most dreadful disorder [ibid., p. 740]".

Other Scot intellectuals, James Mill; Thomas Macaulay; Thomas Malthus and W. T. Thornton, put forward many related arguments. But the Classic liberal case for State responsibility of education, and for compulsory education, was made most forcefully by John Stuart Mill. The following reference from modern literature renders Mill's assertions even more convincing:

North (1992) makes a crucial distinction between institutions and organisations. Organisations are defined as groups of individuals bound by common objectives, including all political, economic, educational and social bodies. Institutions are defined as the rules that give a structure of incentives and constraints. Institutions and organisations then interact, with the institutional structure determining organisations, which in turn influence institutional change. He uses a formal definition that institutions define and limit the choice set of individuals. ${ }^{1}$

Writing in the 19th century, Mill effectively addressed the question of limiting the choice set of individuals: as an advocate of liberty, he needed to justify state interference with individual rights. Of all the arguments against state intervention to impose compulsory education, the most powerful came from those who argued that the state ought not to interfere with the rights of parents to choose what is best for children and their families. Regarding compulsory schooling of the children, Mill argued that a person: "ought not to be free to do as he likes in acting for another, under the pretext that the affairs of the other are his own affairs. The State, while it respects the liberty of each in what specially regards himself, is bound to maintain a vigilant control over his exercise of any power which it allows him to possess over others. This obligation is almost entirely disregarded in the case of the family relations, a case, in its direct influence on human happiness, more important than all

\footnotetext{
${ }^{1}$ Under the lofty assumption of the objective rationality of the governance, this, in author's opinion, is the best paradigm for arriving at the optimum consistency between the positive law and the natural law. Indeed, this distinction reduces even the family and belief system in human society to mere organisations. The most consistent part of this paradigm is its compatibility with the paradox of universe: the intangibles, rules, determining the tangibles, organisations, and vice versa, i.e. harmony out of conflict.
} 
other taken together......it is in the case of children that misapplied notions of liberty are a real obstacle to the fulfillment by the State of its duties. One would almost think that a man's children were supposed to be literally, and not metaphorically, a part of himself, so jealous is opinion of the small interference of law with his absolute and exclusive control over them [Mill (1967), p. 128]". Mill strongly held that it is the responsibility of the state to compel the education of "every human being who is born its citizen [ibid.]" and that the state "ought not to leave the choice to accept or not to accept education in the hands of parents [ibid.]". Mill spelled out the double duty of the parents, toward the children themselves and toward the members of the community who suffer from the consequences of ignorance and want of education in their fellow citizens. He wrote: "It is therefore an allowable exercise of the power of government to impose on parents the legal obligation of giving elementary education to children [ibid.]”.

Finally, the dawn of the 3rd millennium is leaving behind a century which made education as much an experimentation subject as it widened the spread of it. However, the Classicals' advocacy of the state responsibility for educating the masses is as convincing as ever, especially for the developing countries: "In some cases the state of the society necessarily places the greater part of individuals in such situations as naturally form in them, without any attention of government, almost all the abilities and virtues which that state requires, or perhaps can admit of. In other cases the state of the society does not place the greater part of individuals in such situations, and some attention of government is necessary in order to prevent the almost entire corruption and degeneracy of the great body of the people [Smith (1937), P. 735]”.

\section{HIGHWAY TO HEAVEN: JOURNEY ROUND THE CENTURIES}

Adoption of a compulsory education policy was often established in societies before they began rapid economic growth and when per capita incomes were low. The historical evidence delinking mass education from the level of national and per capita income is persuasive. In many countries governments often introduced compulsory education when levels of poverty were high: German municipalities in 1524; Massachusetts in 1647; Scotland, Austria and Sweden in the late 18th and early 19th centuries; Japan in 1872; newly independent South Korea and Taiwan shortly after the World War II.

Mass education spread throughout much of the Europe prior to Industrial Revolution. By the early part of the 18th century, more than 50 percent of the Swedish population was literate. Similar high rates of literacy were reported in Protestant England, Scotland and the Netherlands, all prior to the Industrial Revolution, but not in the Catholic and Orthodox regions of southern and eastern 
Europe [Cipolla (1969)]. ${ }^{2}$ Germany and Scotland were the first European countries to establish the principle of compulsory school attendence. Though neither country adopted compulsory education for some time, the religious pronouncements of Luther and Knox linked the national religion to the educational duties of both the State and its citizens [Strauss (1981)]..$^{3}$

As early as 1528, the government of Saxony provided for the establishment of Latin schools in every village and town. But systematic, large scale state intervention in education was to wait the rise of the Prussian State. In 1817, William III issued a decree ordering all children from ages five to twelve to attend school if a school existed nearby. In 1836, the Prussia initiated a programme of building Volksschulen (elementary schools). Local, secular boards answering to the state administration were formed, with the local clergy serving as superintendents and school inspectors. By 1837, over 80 percent of Prussia's school age children were enrolled in some form of Volksschulen [Alexander (1918)]. By 1849, adult literacy in Prussia was 80 percent, compared with 70 percent for England and 55 percent to 60 percent for France [Cipolla (1969), p. 115]. By 1871, following the unification of German states, school attendence was universal. Adult illiteracy for the country as a whole was only 3.4 percent. The state paid only 5 percent of the public elementary school costs, 75 percent came from local communities and 20 percent from school fees [ibid.]. Austria, the other major German speaking country in Europe, also, by the late 19th century, had a full-fledged state run education system. Apart from Volksschulen, the Austrian Volksschule (educational institutions) included evening schools, high schools, universities, teacher-training institutes, and trade and technical schools. That made up what the emperor of Austria once termed "the admirable system of [Austrian] public education [Endean (1888)]”.

To English moralists education and religion were two closely related instruments for social order and political stability. Education was not regarded as a means of social mobility, nor was investment in education regarded as a means of increasing the country's wealth. The principle of state responsibility for education

${ }^{2}$ This supports the argument that religious establishment universally shares the common feature with all other hierarchies established under the rule of positive law: if not dynamically reformed, the significance of the positive law, in minimising the conflict part of the natural law, is diminished to such an extent that the former starts retrogressively ruling the human society rather than progressively serving it.

${ }^{3}$ Insofar as the religion works through 'fear' and 'hope' traits of the human psyche, it becomes an uphill struggle for the reformers to convince the ignorant 'believers' of their just and warranted cause for unlearning and learning anew. In author's opinion, some established faiths of the contemporary world desperately need 'Martin Luther'. The crusade, however, will essentially become a lot more easier, and far less risky, if the 'believers' indeed have been freed of the behavioural servitude. In order to avoid 'Inquisition' and save one's hide and soul from being 'burnt on the stake', perhaps the best strategy of today's reformer is to campaign for universal school education enveloped by uniform and enlightening curricula. 
was established in 1833 when, for the first time, the British parliament appropriated funds for education. The Education Act of 1870 was followed in 1871 by the London school board legislation which made education for all children up to the age of ten compulsory. There was considerable resistance to the enforcement of compulsory education from the poor themselves, from members of the Anglican clergy, and from the magistrates whose responsibility it was to levy fines upon parents who failed to send their children to school [Stone (1969)].

The American experience with compulsory education highlights the difficulties in a highly decentralised political system where education was largely regarded a local matter. The pressure from social reform organisations and educators was directed primarily at local governments. Not until the 1930s there was much success with national legislation when the principle, that the state had the right to intervene on behalf of children and that children were better off if they remained in school at least until they were sixteen, and preferably until they completed high school, became accepted throughout the country, but not without a long political struggle. Reformers' efforts to raise the school leaving age were mainly opposed by the Catholic Church, whose leaders charged that state legislation was an invasion of parental rights, that it would create poverty by reducing family earnings (through child labour) and that it would overcrowd parochial classrooms [Bowles (1976)].

Japan is perhaps the only example in the world which was well on the way toward universal literacy even before the state started to play an effective role in the establishment of compulsory universal education. By the end of Tokugawa era, prior to Japan's opening to the West, prior to the Meiji restoration, and prior to Japan's industrialisation, the majority of town dwellers, with a settled occupation, and a good proportion of farmers, of middling status, were literate. By 1870, perhaps half the male population of Japan could read and write simple Japanese, keep accounts, and read public documents and newspapers [Dore (1965), p. 3]. But Tokugawa schools, like those of the 19th century England, sustained status divisions, commoners were excluded from "learning appropriate to the world of rulers" [Dore (1964), p. 179]. The Meiji leadership was more egalitarian and enthusiastic about mass education. A famous school regulation of 1872 begins "without distinction of class and sex, in no village shall there be a house without learning, in no house an ignorant individual. Every guardian, acting in accordance with this, shall bring up his children with tender care, never failing to have them attend school [Passin (1965), p. 211]”. The Tokugawa emphasis on education, suited to one's status, eventually ended and between 1880 and 1900 the Japanese government increased the primary school attendence from 41 percent of the six-to-thirteen age group to 82 percent. In 1910, 98 percent of that age group was attending school [Dore (1964), p. 189]. Since the Japanese government emphasised state rather than private education at the primary school level, Japanese children of all social classes shared the same kind of schooling 
for the first six years of school, reading the same text books, learning the same poems, acquiring the same values. ${ }^{4}$ The educational system also facilitated high rates of intergenerational social mobility, and thereby weakened class divisions. While social mobility would not have been possible had Japan not simultaneously experienced a high rate of economic growth, the high growth rate was itself made possible by the expansion of education, including the growth of technical and vocational education in the upper elementary schools.

Historically, Chinese governments have regarded education as serving State goals. China's 19th century Qing rulers were concerned with ideological control [Borthwick (1988), p. 1]. While the rulers of imperial China regarded mass education as a political threat, the post-imperial rulers regarded mass education as a step toward bridging differences between the elite and the masses and developing China as a military and industrial power. It is estimated that in 1949 only 20 percent of the Chinese population was literate and that only one-fourth of the children were in primary school. In 1982, 93 percent of all Chinese children attended primary school; 70 percent completed 6th grade; 83 percent of the urban and 79 percent of the rural primary-school graduates proceeded to junior secondary education; and China's adult literacy rate had risen to 68 percent [Hayford (1987)]. China's success in achieving a high enrolment and high retention rate is linked to a strong commitment by the Communist Party Central Committee and State Council to the achievement of universal literacy [Bhola (1984)]. However, the major expansion of primary and secondary school enrolment took place during the Cultural Revolution. It was a period in which the state saw education as an instrument for creating a more ideologically committed population. Ironically, this policy was consistent with Smith's assertions that "they [the instructed masses] are, upon that account, less apt to be misled into any wanton or unnecessary opposition to the measures of the government. In free countries, where the safety of the government depends very much upon the favourable judgement which the people may form of its conduct, it must surely be the highest importance that they should not be disposed to judge rashly or capriciously concerning It [Smith (1937), p. 740]".

Taiwan was a Japanese colony from 1895 until the end of World War II. The Japanese governors of Taiwan were eager to expand elementary school education for the Taiwanese. In the early years of colonial rule the Japanese created a system of government-run common schools intended to compete with missionary and private Chinese schools. Under pressure from the Taiwanese, for more and better education, the Japanese authorities revamped the educational system in 1919. Under the new system, all children were to attend a common school for six years and thereafter

${ }^{4}$ This, perhaps, provides the best explanation why 'Made in Japan' is the 'best seller' in the world. Not surprisingly, the best strategy to accumulate the largest pool of human capital is to provide equal opportunity to everybody and let them compete unhindered for excellence through meritocracy. 
tracked into a variety of schools, commercial schools, agricultural and forestry schools, and various preparatory programmes leading to normal school, medical school, and other professional schools. Existing private schools were allowed to continue, but new private schools could only be created for vocational studies or for the handicapped. Only 21 percent of the school-age children were in elementary school in 1919. With the new system it rose to 25 percent in 1920. It rose more rapidly in late 1930s. By 1943, 65.7 percent of school-age children were attending elementary school. The government introduced, in 1943, compulsory elementaryschool education and closed down the handful of private schools. The following year 71 percent of Taiwanese school-age children were in school [Tsurumi (1977), p. 224]. When Taiwan was returned to China in 1945, the Japanese legacy to the newly independent government was one of the most developed elementary-school systems to be found in former colonial countries. ${ }^{5}$ With the movement of the Nationalist Government from the mainland to Taiwan, the United States became committed to the island's development and provided substantial resources. The new leadership regarded education as central to its concerns, both for socio-economic development and for creating a loyal population. However, it is difficult to ascertain the extent to which the diffusion of popular education that preceded Nationalist rule facilitated the extraordinary economic growth rate in Taiwan after $1950 .{ }^{6}$ By 1980 all six-to-twelve years old were in school, 90 percent of the twelve-to-fifteen age group and 26 percent of the eighteen-to-twenty two years old were enrolled with the educational institutions [Thomas and Postlethwaite (1983), p. 106]. ${ }^{7}$

When the Japanese took over in 1910, the educational system prevalent in Korea, as in the case of Taiwan, was elitist, confined to males and prestigious. Only a handful of Koreans attended school and literacy levels were low. The system was based on Confucianism. Japanese supplemented the traditional Confucian schools by creating a

${ }^{5}$ Crediting this distinguishably admirable legacy, Tsurumi wrote, "with the exception of the Americans in the Philippines, no other colonial power in Asia or elsewhere approached native education with anything like the seriousness of purpose of Japanese educators in Taiwan. The care that went into formulating and executing educational plans was outstanding”, see, E. Patricia Tsurumi, Japanese Colonial Education in Taiwan, 1895-1945, Cambridge, 1977, p. 224.

${ }^{6} \mathrm{~A}$ land-reform policy combined with incentives to farmers increased agricultural productivity by 80 percent between 1949 and 1960. An export-oriented industrial policy resulted in an increase in trade from one third of a billion dollar annually in the 1950s to $\$ 31$ billion in 1979. Per capita income leaped from $\$ 40$ in 1950 s to $\$ 2,000$ in 1980 . These developments were surely facilitated by the presence of a population with at least six years, and by the late 1960s nine years, of schooling.

${ }^{7}$ One indication of the high value the Chinese place on education is the high status accorded to the members of the teaching profession. Surveys of occupational prestige report that university professors are among the highest in the prestige ranking, that secondary-school teachers rank on the same level as doctors and engineers, and that elementary-school teachers were ranked along with journalists and policemen, see R. Murray Thomas and T. Neville Postlethwaite (ed.) Schooling in East Asia, OUP, 1983, p. 131. 
parallel system of secular public education. Over a period of thirty years, the Japanese expanded the schooling network and increasingly enrolled Korean children. By 1941, 1.8 million children attended school and the government provided free textbooks and free lunches in public schools. ${ }^{8}$ The Japanese authorities also consistently regulated private school, including those run by Christian missionaries [Tsurumi (1984) and Robinson (1984)]. In 1945, Korea was freed from the Japanese rule. Subsequent to the onset of Korean War in 1950, the country, partitioned in North and South, came under the influence of the former Soviet Union and the United States respectively. In both portions of the Korea, the governments emphasised education. Both parts also suffered from the consequences of a prolonged, from 1950-53, bloody Cold War, camouflaged as civil war, which brought considerable destruction to school buildings. But the invaluable legacy of the Japanese colonial rule was continued and governments in both parts viewed education as high priority investment, specifically at primary and secondary school levels. South Korea's remarkable economic growth, that started in the early 1960s, was accompanied by, and to a considerable extent facilitated by, an expanding educational system. The state moved in stages. From 1955 to 1970 the emphasis was on the quantitative expansion of primary schools; after 1965 greater attention was given to increasing the number of junior and senior secondary schools. Compulsory education, initially for six years in 1948, was extended to 9 years of schooling. The educational system was directed at providing a minimal education to the entire population. By the end of the 1970s and in early 1980s, 99 percent of all the elementary-school-age children and one-fourth of the total population of South Korea were in school respectively. The state put considerable resources into investment in teachers training institutions and vocational schools. Students in the former were exempt from fees, and males were exempt from military service if they agreed to teach at least for two years in public elementary schools after graduating [ibid.]. Although only three percent of GNP was expended on education in 1979, in budgetary terms it was a hefty 19 percent of total government expenditure. Weiner and Noman (1995, p. 171), perhaps misled by the relative share in GNP, reckons it a lower investment than in many other developing countries. In author's opinion, it was, on the contrary, impressively high investment, both in absolute magnitude and relative budgetary allocation, compared to almost all of the developing countries. ${ }^{9}$ An investment justified by interminable dividends, unmistakably manifest in per capita income from \$ 83 in 1961 to \$ 7, 970 in 1998 and, even more, in South Korea’s speedy recovery from “Asian Crisis”.

\section{III. 'BACK' TO FUTURE: THE TINSEL TIGER}

In Pakistan, human resource development has been neglected to a worrying extent.

${ }^{8}$ This may be nicknamed as 'pusher' strategy. Though it involves considerable cost, the expenditure is justified by the large positive externalities attached to it.

${ }^{9}$ For the support of this assertion, see UNESO, Statistical Year Book, 1995, Paris. 
Even after over half a century of its existence, the country ranks 120th on the scale of the world human development indicators. ${ }^{10}$ The situation of mass education is particularly alarming. Table 1 and Table 2 together manifest Pakistan's record of dismal performance within the developing countries. Comparative scenarios presented here compare Pakistan's performance at the primary and secondary levels of education ${ }^{11}$ which together may be used as perhaps the most appropriate common denomination for determining literacy rate. ${ }^{12}$ The figures show that Pakistan's score, unfortunately, is the lowest by any scenario of comparison.

Scenario One compares Pakistan's performance within the low income economies group. The country most certainly appears in desperate need of catching up even within this laggard category.

Scenario Two compares Pakistan's position with various regions within the developing countries. The regions in Table 1 and Table 2 are listed in descending order of the weighted average of GNP per capita. Although Sub-Saharan Africa is usually rated the poorest region in the world, South Asia appears to have the largest number of poor by the GNP per capita measure. ${ }^{13}$ It also ranks lowest in literacy rates for both men and women. But comparison of these regions with Pakistan indeed warrants serious heart searching on the part of Pakistani establishment at all levels of decision-making and influence. The rhetoric of 'programme 2010' apart, the country is entering into the next millennium with literacy rate far below the corresponding figure of the most impoverished region in the world, the Sub-Saharan Africa.

${ }^{10}$ During the 1980s, Pakistan was the fifth fastest growing economy in the world out of 160 countries. But the country was ranked a dismal 120th by the UNDP regarding human resource development indicators. See, Human Resource Development Report, 1992, UNDP, p. 2.

${ }^{11}$ Primary school enrolment data are estimates of the ratio of children of all ages enrolled in primary school to the country's population of primary school-age children. Gross enrolment ratios may exceed 100 percent because some pupils are younger or older than the country's standard primary school age. Secondary school enrolment data are calculated in the same manner.

${ }^{12}$ There are four measures for ascertaining the quantitative effectiveness of schooling. The first is the enrolment ratio for primary school; that is, what proportion of children of primary school age are enrolled in school (this is the most commonly used, but least reliable, measure. Enrolment does not necessarily mean attendance and government educational attendence do not distinguish between the two, though school attendence is more meaningful measure). A second is the survival rate to the final grade of primary education, usually the 5th or 6th grade (this measures the retention ratio and, as an indication of continuous schooling, is the more useful and reliable measure. It is also a useful measure of how effectively resources are being employed. A considerable amount of educational resources is wasted on children who are not in school long enough even to acquire literacy. Four or five years of schooling is what is generally needed to ensure life-long literacy). The third is the transition rate from primary to secondary education. And the fourth is the adult literacy rate which is defined as the proportion of the population age 15 years and older who can, with understanding, read and write a short, simple statement on their everyday life (this is only one of three widely accepted definitions, and its application is subject to qualifiers in a number of countries. See, World Development Report (1997, p. 251 and p. 255).

${ }^{13}$ Weighted average of GNP per capita of these regions in 1995 was US\$ 3320, US\$1780, US\$ 800, US\$ 490 and US\$ 350 respectively. See ibid., Table 1, p. 215. 
Table 1

(Primary Education)

Access to Formal Education in Pakistan: Comparative Scenarios

\begin{tabular}{|c|c|c|c|c|c|c|c|c|}
\hline \multirow[b]{3}{*}{ Group* Region*/ Country } & \multicolumn{4}{|c|}{$\begin{array}{l}\text { School Enrolment } \\
\text { (\% of Age Group) }\end{array}$} & \multirow{2}{*}{\multicolumn{2}{|c|}{$\frac{\% \text { Reaching }}{\text { Girls }}$}} & \multicolumn{2}{|c|}{ Grade $4 * *$} \\
\hline & \multicolumn{2}{|c|}{ Girls } & \multicolumn{2}{|c|}{ Boys } & & & \multicolumn{2}{|c|}{ Boys } \\
\hline & 1980 & 1993 & 1980 & 1993 & 1980 & 1993 & 1980 & 1993 \\
\hline 1. Low Income Economies & 81 & 98 & 104 & 112 & - & - & - & - \\
\hline 2. (a) Latin America and Caribbean & 105 & - & 108 & - & - & - & - & - \\
\hline (b) Middle East and North Africa & 74 & 91 & 98 & 103 & - & - & - & - \\
\hline (c) East Asia and Pacific & 102 & 116 & 118 & 120 & - & - & - & - \\
\hline (d) Sub-Saharan Africa & 68 & 65 & 90 & 78 & - & - & - & - \\
\hline (e) South Asia & 61 & 87 & 91 & 110 & - & - & - & - \\
\hline Pakistan & 27 & 49 & 51 & 80 & 41 & 45 & 53 & 55 \\
\hline 3. (a) India & 67 & 91 & 98 & 113 & 52 & - & 57 & - \\
\hline (b) Sri Lanka & 100 & 105 & 105 & 106 & - & 96 & - & 95 \\
\hline (c) Bangladesh & 46 & 105 & 76 & 128 & 30 & 46 & 29 & 44 \\
\hline 4. (a) Indonesia & 100 & 112 & 115 & 116 & - & - & - & - \\
\hline (b) Malaysia & 92 & 93 & 93 & 93 & - & 99 & - & 98 \\
\hline (c) Saudi Arabia & 49 & 73 & 74 & 78 & 90 & - & 81 & - \\
\hline (d) Syria & 88 & 99 & 111 & 111 & 91 & 96 & 94 & 97 \\
\hline (e) Egypt & 61 & 89 & 84 & 105 & 83 & - & 75 & - \\
\hline 5. (a) Cambodia & - & 46 & - & 48 & - & - & - & - \\
\hline (b) Vietnam & 106 & - & 111 & - & 67 & - & 71 & - \\
\hline
\end{tabular}

Source: World Development Report 1997. Table 7, pp. 226-27.

* Figures are weighted averages.

** The proportion of children starting primary school in 1980 and 1988 who continued to the 4th grade by 1983 and 1991 respectively. 
Table 2

(Secondary Education and Adult Illiteracy)

Access to Formal Education in Pakistan: Comparative Scenarios

\begin{tabular}{|c|c|c|c|c|c|c|}
\hline \multirow[b]{3}{*}{ Group*/ Region*/ Country } & \multicolumn{4}{|c|}{$\begin{array}{l}\text { School Enrolment } \\
\text { (\% of Age Group) }\end{array}$} & \multirow{2}{*}{\multicolumn{2}{|c|}{$\begin{array}{c}\text { Adult Illiteracy } \\
\text { (\%) } \\
1997 \\
\end{array}$}} \\
\hline & \multicolumn{2}{|c|}{ Girls } & \multicolumn{2}{|c|}{ Boys } & & \\
\hline & 1980 & 1993 & 1980 & 1993 & Female & Male \\
\hline 1. Low Income Economies & 26 & 41 & 42 & - & 42 & 22 \\
\hline 2. (a) Latin America and Caribbean & 41 & - & 40 & - & 14 & 12 \\
\hline (b) Middle East and North Africa & 32 & 51 & 52 & 65 & 50 & 27 \\
\hline (c) East Asia and Pacific & 36 & 51 & 51 & 60 & 24 & 9 \\
\hline (d) Sub-Saharan Africa & 10 & 22 & 20 & 27 & 54 & 34 \\
\hline (e) South Asia & 18 & 35 & 36 & - & 63 & 36 \\
\hline Pakistan & $3^{* *}$ & $8^{* *}$ & $8^{* *}$ & $16^{* *}$ & 75 & 45 \\
\hline 3. (a) India & 20 & - & 39 & - & 61 & 33 \\
\hline (b) Sri Lanka & 57 & 78 & 52 & 72 & 12 & 6 \\
\hline (c) Bangladesh & 9 & 12 & 26 & 26 & 73 & 50 \\
\hline 4. (a) Indonesia & 23 & 39 & 35 & 48 & 20 & 9 \\
\hline (b) Malaysia & 46 & 61 & 50 & 56 & 19 & 10 \\
\hline (c) Saudi Arabia & 23 & 43 & 36 & 54 & 38 & 19 \\
\hline (d) Syria & 35 & 42 & 57 & 52 & 43 & 13 \\
\hline (e) Egypt & 39 & 69 & 61 & 81 & 66 & 35 \\
\hline 5. (a) Cambodia & - & - & - & - & 47 & 20 \\
\hline (b) Vietnam & 40 & - & 44 & - & 11 & 5 \\
\hline
\end{tabular}

Scenario Three presents Pakistan's uncomfortable position relative to its three major South Asian counterparts. Not to speak of India, a country with the largest number of poor on the planet, even Bangladesh, one of the so-called basket cases, deserves some applause in comparison to Pakistan. But the country which really stands out of this dismal scenario is Sri Lanka, a small peripheral country ravaged by ethnic violence and incessant insurgence, yet providing guidance to 87 percent of its women and 93 percent of its men to find the route to self-determination, one of the basic human rights. ${ }^{14}$ Finally, Maldives and Bhutan which do not even have the magnitude to appear in regular tables of the 'World Development Report', with 96 percent and 42 percent literacy rate respectively leave Pakistan to champion only over Nepal in South Asia.

${ }^{14}$ A study by the British Council perhaps rightly concluded that "despite all shortcomings, the level of growth of the educational system is impressive, and the reforming of the secondary school system and curriculum a considerable achievement. Sri Lank, after Japan, can claim to have one of the most developed systems in Asia”. See, British Council, Educational Profile: Sri Lanka, Colombo: The British Council, 1977, p. 29. 
Scenario Four is no less humiliating. It compares Pakistan's literacy performance with five major Muslim countries. Given the 'Islamisation' rhetoric of every successive Government of Pakistan, ${ }^{15}$ the abysmal performance of the country on the educational front relative to its Muslim counterparts reduces the significance of 'Islamisation' to sheer instrumentalisation of a slogan. Indonesia and Malaysia clearly stand out in comparison by all measures, while Syria, Saudi Arabia and Egypt have so far outperformed Pakistan by wide margins.

Scenario Five is selected to emphasise the point that poverty coupled with internal and external strife may temporarily interrupt but cannot hinder the developmental efforts of the nations who have their priorities clearly and consistently defined. Cambodia and Vietnam, merciless victims of the Cold War strategy of the Super Powers, have been through the bloodiest and longest civil wars of the documented human history. Both are poor countries, as their per capita income is a little over half of the GNP per capita of Pakistan ${ }^{16}$. But both countries have a lot to offer to Pakistan in terms of important lessons in development economics. The surface message is clear: get the fundamentals right. While Cambodia is catching up fast, Pakistan's literacy achievement clearly appears a far cry compared to Vietnam's literacy rates of 91 percent and 96 percent for women and men respectively. No wonder both countries have graduated to join the ASEAN, one of the three regions in the world which count in economic terms. ${ }^{17}$

\section{BLACK BOARD JUNGLE: WE WILL CRY TOMORROW}

What forces have propelled a higher commitment to school education in many other developing countries? Are they the same or similar to those that inspired Western Europe and the United States? In Part II, an examination of three developing countries in Asia that have been successful in expanding primary-school education reveals the variety of forces at work, and the ways in which these countries differ from Pakistan in their approach to education. The Chinese experience is an evidence of successfully dealing with the problems of expanding school education in a country far more populous than Pakistan. Taiwan provides an example of how schooling, initially expanded under colonial auspices, was used by the successor regime as the basis for the development of an educational system that

\footnotetext{
${ }^{15}$ Especially since 1977 when to anchor its falling reign the first PPP government, led by Zukfikar Ali Bhutto, introduced drastic 'reforms' for the 'Islamisation' of Pakistan. Not only the legacy was continued, it was rather deepened by the Zia-Ul-Haq's military regime which instrumentalised the slogan of Islamisation for 'legitimising' its illegitimacy to win the Cold War for the Western Block.

${ }^{16}$ GNP per capita of Pakistan, Cambodia and Vietnam in 1995 was US\$ 460, US\$ 270 and US\$ 240, respectively. See ibid. p. 214

${ }^{17}$ Most of the futuristic literature divides the world into three main regions of North America, Europe and East Asia. As economic producers, Latin America, Africa, the Middle East and Indian Subcontinent are treated in a relatively sketchy manner. See MCrae (1998) and Kennedy (1994).
} 
helped to transform the island's economy and social structure. South Korea, on the other hand, provides a contrasting example of an exceedingly poor country with a low level of literacy and school enrolment at the time of independence that succeeded in the course of a single generation in transforming mass education.

Modern states regard education as a legal duty, not merely a right; parents are required to send their children to school, children are required to attend school, and the state is obligated to enforce compulsory education. But this is not the view held in Pakistan. Pakistan has never declared that it intends to make school education compulsory. ${ }^{18}$ Korea, China and Taiwan introduced compulsory education shortly after the 2nd World War when their per capita incomes were no greater than those of Pakistan. Many countries of Africa with incomes lower than Pakistan have expanded mass education with impressive increases in literacy. Botswana, Cameroon, Equatorial Guinea, Gabon, Gambia, Ghana, Ivory Coast, Lesotho, Libya, Madagascar, Mauritius, Rwanda, Swaziland, Zambia and Zimbabwe have literacy rates between 50 percent to 75 percent [World Bank (1999)]. In many countries, theologies or secular ideologies have stood for a system of national education aimed at social equality. In Pakistan, on the contrary, the vast gap regarding the country's mass education is puzzling. ${ }^{19}$

Schooling in Pakistan is multiple-tier and so muddled that it cannot be designated the status of a system. The children of the poor are prevented from getting an equal chance to flourish academically. Pakistan's policy-makers have not regarded mass education as essential to the country's modernisation. They have instead put

\footnotetext{
${ }^{18}$ It is a principle of policy of the State of Pakistan to: 'remove illiteracy and provide free and compulsory secondary education within minimum period' (see Article 37 (b), The Constitution). But it should be noted that law permits but does not require local authorities to make education compulsory. The law relating to primary education in Pakistan has been consolidated under the Provincial Primary Education Ordinance, 1962. This Ordinance gives the provincial government the power to introduce compulsory primary education in any district. In such an area, the parent of a child is to enrol the child in a recognised school until the child has completed eight years of schooling (see Section. 18, ibid.). It is only an enabling legislation, and does not imply compulsory primary education as a social obligation of the state. In brief, the provincial government can, but do not have to, introduce compulsory primary education. Practically, school education in Pakistan is not compulsory: there are no enforcement authorities, no provisions for the compulsory registration of names and birthdays of children, no enumeration registers, no procedures for issuing notices to parents and guardians whose children are not attending schools, and no penalties for failing to send children to school. No cases against parents or guardians are brought before administrative agencies or courts. Nor have elected or appointed officials in the provincial or central governments pressed for the enforcement of compulsory education legislation.

${ }^{19}$ Especially, in a country whose governing elite always professes to be practising Muslims before everything else and many of whose bureaucrats, politicians and intellectuals are advocates of an intrusive Islamic State. It is indeed regrettable that in spite of the heavy mandate of the recently dismissed 'Islamising' Muslim League government, the destination of universal primary education in Pakistan remains as far away as ever. Readers further interested in exploring these dilemmas are referred to footnotes 3 and 4 .
} 
resources into semi-elite government schools, state-aided private schools, and higher education in an effort to create an educated class that is equal to educated classes in the West and that is capable of creating and managing a modern enclave economy. There are many Pakistani brand 'Eatons' which coexist with the often substandard public schools and other private schools. The narrow upstream of the 'Eatonians' is continuously widening the already wide gulf separating the English-speaking elite, which controls the government, economy and the highest educational and research institutions, and the huge masses with fewer amenities, limited vernacular knowledge and no prospects of economic or social mobility.

In Pakistan, public schooling has scarcely played any role in cultural revitalisation, social mobility and social progress. The present education system is good for nothing. The schools do not build character nor are they able to prepare the children for self-employment. For the development of the country the social values like work, discipline, communal and environmental harmony, equality and equity should be given to the children in the school. But both the formal curricula and actual teaching scarcely inculcate these values. Schools do not prepare for careers. The majority thinks that if we go to school we at least should have an office, if not whitecollar, job. There is no regard for manual labour in the educational system. Hence, many of the school leavers become antisocial elements. Education is well paid now and the teachers are organised, but they do not teach in a sympathetic and devoted manner. They themselves are to be blamed for the disrespect and disregard they get from society and students. ${ }^{20}$ A very few exceptions apart, the love for students and passion for knowledge is largely absent. Teachers have their unions and once they enter the school system they hardly ever get terminated. No league tables are ever prepared or published for public schools. Moral values rightly need to be emphasised in education, but moral values cannot be taught to the students until the teachers have sufficient training in such values themselves.

The downstream private schools are hardly any better than public schools. The rules for regulating private schools either do not exist or they hardly ever get implemented. Ruthless commercialising has turned private schooling in Pakistan into a stinky and sprouting trade ${ }^{21}$. Middle-stream, semi-elite private schools are charging

${ }^{20}$ In the author's opinion, two professions are of fundamental importance in every society. Teaching and Health. While the latter takes care of its physical health, the former guarantees the spiritual health of a nation. The society where one or both of these professions are invaded by the mercenary 'alien bodies' gets in trouble. In Pakistan, unfortunately, both these professions are demonstratively exhibiting 'terminal mercenary syndrome', leave alone simple infection: the overwhelming majority of both doctors and teachers, from bottom right up to the top, appear to be ruthless and disgraceful 'athletes' in the rat race.

${ }^{21}$ Leave alone big cities, even in small peripheral towns, every other street corner boasts of a board advertising the merchandise. Yes! There is the promise of your child getting 'elite' education, mostly in a suffocating environment, under the instructions of the 'esteemed mentor' whose wages may be lower, more restrictive and uncertain than that of the part-time domestic helpers. 
hefty amounts for teaching widely different curricula that neither inculcate the trait of unity non-uniformity in the raw minds of the pupils. Worst of all, there is a booming business of 'teaching shops' which range from 'single commodity vendors', who are mostly teachers employed in the public schools, to 'departmental stores' and 'super markets'. Yet the latter, in spite of their lush, have to face a 'perfectly competitive market' for buying exam papers, examination centres and examiners.

The only good news about education in Pakistan is that so many people have prepared root-and-branch plans for reforming it. Since the making of Pakistan, almost a dozen educational reports and four major education policies have been produced. ${ }^{22}$ Every successive educational policy has been greeted with increased cynicism. Cynicism in that once again another committee has recorded itself in the history book of education. It is indeed hard to listen to today's education gurus without feeling that it has all been said before. There have been a spate of statesponsored and other programmes for 'universalisation of education' and 'total literacy'. ${ }^{23}$ The ease with which radical terminology is used in these programmes itself makes them very suspect. The issues of nature of content, pedagogy, implementation strategies, linking up with larger socio-economic processes, understanding and giving space to perspectives and aspirations of masses have never been mentioned, leave alone spelled out.

Finally, as a reform programme, education is helpful only if the social and political understanding of the 'educationists' is strengthened by honest search, human concern and with the objective of resisting any form of subjugation and domination. Many a time 'educationists' are blinded by their ambitions, vested interests and insecurities, and then they impede the process of such an honest search. ${ }^{24}$ What may be claimed a radical or progressive education programme from urban-biased middle-class framework could be totally irrelevant in the perception of the masses whose lack of interest is often interpreted as ignorance or lack of awareness. All the education policies of Pakistan indeed clearly reflect the arrogance of the intelligentsia that they understand the problems and know the solutions best. Such an attitude will have to be reformed first. But, unfortunately, it is always easier to design programmes for the 'uneducated' but, however warranted, much more

${ }^{22}$ They include, All Pakistan Education Conferene 1947; Education Conference 1951; National Commission on Education 1959; Education Policy with Nationalisation 1972; National Education Policy 1979; and Education Policy 1992

${ }^{23}$ For example, the doomed Nai Roshni Schools programme of the 1979 Education Policy; and rhetoric of the 1992 Education Policy, aiming at universalising primary education and raising the literacy ratio to 70 percent by 2002 .

${ }^{24}$ There needs to be provided an explanation for why Pakistan's policies toward education are different from those of so many other countries, why is the Pakistani State unable or unwilling to deal with the high illiteracy, high dropout rates and escalating deterioration of education at all levels, and, most importantly, why the government commissions reviewing education policies have never called for compulsory education? 
difficult to 'educate' the 'educator' because it involves the formidable challenge of finding the black cat in a dark room. The worst part is that the 'black cat' despises the game and hardly ever goes to the 'dark room' in the first place.

\section{TWINKLE TWINKLE LITTLE STAR: YOUR DREAM IS MINE}

If virtue gets its reward in heaven, education gets its payoff on earth. Especially, school education, on almost every measure, is a highly remunerative investment. Psachroupoulas (1980) estimated the returns to different levels of education on data for 22 poor countries. His findings revealed that the highest private and social rates of return, 29 percent and 27 percent respectively, were on primary education. ${ }^{25}$

In a fundamental sense the school as an institution is linked to the emergence of modern civil society. In almost all nations of the world, a consensus is found on the view that the family could no longer be relied upon as the institution for the transmission of those values, attitudes, skills and knowledge that are essential in the modern world. Teachers appointed by and financially dependent upon the state are regarded as more effective than parents in promoting whatever notions the state regards as essential. The school has emerged as a unique modern institution, indeed the only institution in which, with the introduction of compulsory education, everyone in the society is required to participate. Notions of equality, equity, merit, mobility, citizenship and nationality are now universally regarded as societal as well as state goals. The school is the favourite institution for the promotion of all these notions. At some historical moment every developed country of today introduced the principle of compulsory education. The pace of industrial development and modernisation were important, but what is more striking is that mass education, and most of the time compulsory education, often preceded industrialisation and urbanisation. That those who emphasised state responsibility for mass education ultimately won does not mean that the policies were the result of their arguments. The experience of both developed and developing countries suggests that those who make the argument matter: the difference among various countries that made education compulsory depended on the attitude of those within the state apparatus and upon those outside who could successfully influence the state policies. The upshot is that the opinion of politically influential forces and the institutional structure of the state appear to be more important, in explaining the timing of the state effectively assuming the responsibility, than the level of economic development, per capita incomes or the prevalence of poverty.

${ }^{25} \mathrm{~A}$ recent study carried out by the World Bank on data for Pakistan, during the period 1974-92, reports the highest rate of return, 20 percent, on primary education. The secondary education ranks fourth, 14 percent, falling only behind the rate of return on infrastructure and all projects, 16 percent and 15 percent respectively. See, Akhtar Hasan Khan, Education in Pakistan, the PDR, 36: 4, Winter 1997, P. 653. 
This study strongly recommends the case for state responsibility of universal, free and compulsory ten years of schooling with necessarily uniform curricula for both public and private schools. ${ }^{26}$ The curricula ought to emphasise creativity rather than rote learning and it must not contain the kind of dogmas which inculcate in raw minds iconism and behavioural servitude. It should rather aim at equipping the children to grow up into rational individuals in a congenial environment guaranteeing collective well being of the society. Market initiative, to provide schooling to those who prefer choice and can afford to pay, should also be encouraged, but with strict regulation and constant monitoring.

There are a great many variations in how Pakistan government could set about making education compulsory. There are also a great many variations in matters regarding the allocation of educational resources, the machinery used to enforce the various laws and so on. Nonetheless, there are some widely shared elements from which policy recommendations can be extracted. What follows is an enumeration of some of these recommendations:

1. Prior to the introduction of compulsion, government should make sure to have effectively put in place a national network of schools that are accessible to all children, both rural and urban.

2. For an effective system of enforcement, school authorities should be required to create registers with the names, birth dates, addresses, and the names of guardians of all children within the community.

3. The successful enforcement of compulsory education laws requires that the target is aimed at achieving universal enrolment of all school-age children and to ensuring that children are actually in attendance. Retention, not simply enrolment, is essential. Parents' responsibility to make their children to attend school must be legislated as enforced law with violation, for other than medical reasons, subject to penalties. When education is compulsory, parents who claim that their children ought not be compelled to attend school because of social or economic reasons must not be accommodated.

4. Education should initially be made compulsory upto the primary level which, at a later stage could be extended to middle school high school levels. The phased extension of compulsory education will provide school authorities the necessary lead time for expansion.

5. Once education is made compulsory, schooling should be provided free by the state. School authorities may also make textbooks free and provide uniforms and lunches to needy children. ${ }^{27}$ Inoculations and other health

\footnotetext{
${ }^{26}$ Footnote 4 highlights the significance of author's recommendations regarding this point.

${ }^{27}$ This 'pusher' strategy, earlier coined in footnote 8 , if carried out effectively, promises the nation 'fat dividends' on its investment after the gestation period of 5 to 10 years.
} 
benefits may be provided as well. These measures, intended to improving well-being of children and reducing or eliminating the cost for parents, should make it less likely that poor parents will try to remove their children from school.

6. Once education is made compulsory, school authorities should be provided power and facilities to take steps to enable and motivate unwilling parents to obey the law.

7. School management authorities must ensure that teachers are present everyday, the boards, books, and other teaching aids are available, and that children are in fact learning, reading, writing, and doing arithmetic.

8. Finally, and most importantly, given that the decision to make education compulsory rests everywhere on the belief in the efficacy of mass education on the part of those who make, influence, and implement education policy, it is essential that some such belief in the value of mass education be firmly held by the governing elite of Pakistan. Without such a conviction, authorities will not commit the resources necessary to establish a national system of school education nor will they make education compulsory.

\section{REFERENCES}

Alexander, T. (1918) The Prussian Elementary Schools. New York: Macmillan.

Arrow, K. J. (1973) Higher Education as a Filter. Journal of Public Economics 2:3 193-216.

Bhola, H. S. (1984) Campaigning for Literacy. Paris: UNESCO.

Borthwick, S. (1988) Education and Social Change in China: The Beginning of the Modern Era. Stanford: Hoover Institution Press.

Bowles, S., and Herbert Gintis (1976) Schooling in Capitalist America: Educational Reforms and the Contradictions of Economic Life. New York: Basic Books.

Cipolla, C. M. (1969) Literacy and Development in the West. Penguin Books.

Dore, R. P. (1964) Japan. In Robert E. Ward and Dankwart A. Rustow (eds) Political Modernisation in Japan and Turkey. Princeton: Princeton University Press.

Dore, R. P. (1965) Education in Tokugawa Japan. Berkeley: University of California Press.

Endean, J. R. (1888) The Public Education of Austria: Primary, Secondary, Technical, Commercial. London: Simpkin, Marshall and Co.

Hayford, C. W. (1987) Literacy Movements in Modern China. In Robert F. Arnove and Harvey J. Graff (eds) National Literacy Campaigns: Historical and Comparative Perspectives. New York: Plenum Press.

Kennedy, P. (1994) Preparing for the 21st Century. London: Fontana Press.

Khan, A. H. (1997) Education in Pakistan. The Pakistan Development Review 36:4 647-67.

MCrae, H. (1998) The World in 2020. London: Harper Collins. 
Mill, J. S. (1967) On Liberty (1859) In English Philosopher from Bacon to Mill. New York: Modern Library.

North, D. (1992) Institutions, Institutional Change, and Economic Performance. Cambridge: Cambridge University Press.

Passin, H. (1965) Japan. In James S. Coleman (ed.) Education and Political Development. Princeton: Princeton University Press.

Psachroupoulas, G. (1980) Returns to Education: An Updated International Comparison. In Timothy King (ed) Education and Income. Washington D. C.: World Bank. 73-110.

Psachroupoulas, G. (1984) Contribution of Education to Economic Growth: International Comparisons. In J. W. Kendrick (ed) International Comparisons of Productivity and Causes of the Slowdown. Cambridge: Ballinger. 335-60.

Psachroupoulas, G. (1994) Returns to Investment in Education: A Global Update. World Development 22:9 1325-43.

Robinson, M. E. (1984) Colonial Publication Policy and the Korean Nationalist Movement. In R. H. Myers and M. R. Peattie (eds) The Japanese Colonial Empire: 1895-1945. Princeton: Princeton University Press.

Smith, A. (1937) The Wealth of Nations. New York: Modern Library.

Spence, A. M. (1973) Job Market Signalling. Quarterly Journal of Economics 87:3 355-74.

Strauss, G. (1981) Techniques of Indoctrination: The German Reformation. In H. J. Graff (ed) Literacy and Social Development in the West: A Reader. Cambridge: Cambridge University Press.

Stone, L. (1969) Literacy and Education in England, 1640-1900. Past and Present $4269-119$.

Talik, J. B. J. (1989) Education and its Relation to Economic Growth, Poverty and Income Distribution. World Bank, Washington, D. C. (Discussion Paper No. 46.)

Talik J. B. J. (1994) Education for Development in Asia. New Delhi: Sage Publications.

Thomas, R. M., and N. Postlethwaite (1983) (eds) Schooling in East Asia. Oxford: Pergamon Press.

Tsurumi, E. P. (1977) Japanese Colonial Education in Taiwan: 1895-1945. Cambridge: Harvard University Press.

Tsurumi, E. P. (1984) Colonial Education in Korea and Taiwan. In R. H. Myers and M. R. Peattie (eds) The Japanese Colonial Empire: 1895-1945. Princeton: Princeton University Press.

UNESCO (1995) Statistical Year Book. Paris.

Weiner, M., and Omar Noman (1995) The Child and the State in India and Pakistan. Karachi: Oxford University Press.

World Bank (1999) World Development Report, 1997, and 1999-2000. New York: Oxford University Press. 


\section{Comments}

I would like to begin by commending the author, Mrs Naheed Zia Khan, on a very informative paper on a very important aspect of our life. Education is indeed "fundamental to building a sense of common citizenship, a vehicle for social mobility, and a means of creating an effective workforce". Pakistan is a signatory to the United Nations "Education For All” goals which include universal primary education, raising adult literacy, improving early childhood care, increasing primary learning achievement levels, training in essential skills, and educating individuals and families for a better living.

In the context of this paper, there are a few comments and suggestions which I hope can contribute towards improving the paper and develop some analytical aspects in the arguments.

The first two parts of the paper trace the history of how Classical economists viewed the role of state in education and how education policy guided certain European and Asian nations to develop their education systems and educate their masses. I feel that these parts could have been drastically curtailed as the former is well known while the latter has little relevance to Pakistan and, therefore, to the topic of the paper.

My comments, on the latter three parts of the paper focus on analysis and recommendations:

\section{Analysis}

Part III discusses the situation of mass education in Pakistan in the context of five scenarios:

- Scenario one: Pakistan vs. low income economies;

- Scenario two: Pakistan vs. various regions within developing countries;

- Scenario three: Pakistan vs. its South Asian counterparts (India, Bangladesh and Sri Lanka);

- Scenario four: Pakistan vs. five major Muslim countries; and

- Scenario five: Pakistan vs. two poorer countries (Cambodia and Vietnam).

However, Part IV appears structurally unconnected with the preceding part. One way of strengthening the analytical aspects of this paper can be to relate these two parts. Rather than studying forces which propelled a higher commitment to school education in China, Taiwan and South Korea (societies which greatly differ from Pakistan in economic development, society and culture), the paper should have analysed the forces which improved enrolments and literacy rates in similar societies such as India, Bangladesh and Sri Lanka. A focus on policy which brought about 
improvements in these societies would have yielded a more interesting and more relevant analysis.

\section{Recommendations}

A major weakness of the paper is its set of recommendations. First, they are based on an assertion that it is within the power of Pakistan's State to improve its educational performance. This is an inaccurate assertion as there are many demandrelated factors which influence the situation of education in the country and the State is rendered helpless.

Second, these recommendations are too theoretical and read like a "wish-list" rather than a set of suggestions for a realistic implementation. The establishment of a network of well-equipped schools, easily accessible by both rural and urban children; the maintenance of personal records; the enforcement of legislation for compulsory education, punishing violating parents; free provision of textbooks, uniforms and lunches to poor children; perfect management of teacher attendance and improving learning achievement levels in children will require a society free of poverty, unemployment, corruption and mismanagement. Also, the implementation of these recommendations requires a fiscal system in which there are no budget constraints (in short, a budgetary system which is not over-burdened with debt and defense expenditures so that allocations for education sector could be enhanced to the level required for the implementation of these recommendations). Even a partial implementation of these recommendations will require a revamping of the fiscal setup, involving a drastic change in the tax culture (both for tax collectors and tax payers) and a very high level of political commitment from all relevant quarters. Moreover, the communities will have to re-assume their own responsibility in this regard, which they abandoned decades back, to provide their share in operation and maintenance of local schools.

In reality, the situation is very different. The paper provides only a partial analysis by focusing on the supply side of education and ignoring the demand factors. There are several demand-related factors that have hindered the spread of education in Pakistan, including: (a) the opportunity cost of attending school for children helping at home or in economic activities is very high as poor families need the help of their children at home or at work. Many girls do not attend school as they have to perform household chores while their mother's work; or boys who have to earn to support the family; (b) many conservative families prefer not to send their girls to school as they do not see any benefits of doing so; (c) tribal chiefs have discouraged the demand for education. Hence, supply side improvements alone will not be able solve the problem.

I would also like to record my surprise on the omission of the Social Action Programme (SAP) in a paper related to public schooling in Pakistan. Although it has its limitations but even its worst critics accept that SAP has made a notable improvement 
in female primary enrolments, especially in the rural areas. ${ }^{1}$ Perhaps a note on the achievements and limitations of SAP would add a useful dimension to this paper.

Finally, today, any discussion on schooling in Pakistan is incomplete without mentioning the role of non-formal basic education. In December 1995, the Government of Pakistan approved a project proposed by the Prime Minister's Literacy Commission (PMLC) for the establishment of 10,000 Non-Formal Basic Education schools. Reportedly, 7,117 such schools have been established till now. The total enrolment in the existing Non-Formal Basic Education schools is around 214,000. The NFBE schools are based on the "Home School" model, a teacher is selected by the community, and the five-year primary curriculum is taught in three and a quarter years for primary school age students. Funding for the NFBE schools is provided by the PMLC to the communities through intermediary non-government organisations (NGOs). It covers urban slums, small towns and remote settlements. Although, the Programme experienced a number of shortfalls and resource constraints due to the absence of a long-term management and financial plan but generally it is considered well-designed, cost-effective and has shown some positive contributions, especially towards female literacy in rural areas.

In conclusion let me state that I agree with the author that the main cause of the present deplorable state of our education system is that the service providers, both public and private, have failed to deliver quality education equitably among all segments of the society. However, this is not the only cause and the communities themselves are as much to be blamed for this situation. Most of them just hope and wait for the government to "do the necessary" in this regard, and, unlike the past, make no contribution towards improving the coverage and quality of education in the country.

Rawalpindi.

Eshya Mujahid-Mukhtar

${ }^{1}$ For recent statistics on enrolments and literacy rates, refer to Pakistan Integrated Household Survey, the FBS survey monitoring SAP since 1996. 